\title{
Subject Status Original Result
}

National Cancer Institute

\section{Source}

National Cancer Institute. Subject Status Original Result. NCI Thesaurus. Code C117663.

The outcome of the subject status assessment as originally received or collected. 